\title{
Isocitrate Lyase Activity in Thiobacillus versutus Grown Anaerobically on Acetate and Nitrate
}

\author{
By PIETERNEL A. M. CLAASSEN AND ALEXANDER J. B. ZEHNDER* \\ Department of Microbiology, Agricultural University, Hesselink van Suchtelenweg 4, \\ 6703 CT Wageningen, The Netherlands
}

(Received 24 March 1986; revised 10 June 1986)

\begin{abstract}
In cell-free extracts of Thiobacillus versutus, an organism which has been reported to be isocitrate lyase negative, an isocitrate lyase activity of $52 \pm 18 \mathrm{nmol} \mathrm{min}^{-1}$ (mg protein) ${ }^{-1}$ was observed after anaerobic growth in a chemostat on acetate plus nitrate, i.e. during denitrification. Following growth on succinate plus nitrate, isocitrate lyase activity was only $1 \pm 2 \mathrm{nmol} \mathrm{min}^{-1}$ (mg protein $)^{-1}$. In cell-free extracts derived from aerobic chemostat cultures isocitrate lyase activity was always nil. The identity of the enzyme was analysed using a number of different methods, namely $(a)$ three different enzyme assays, $(b){ }^{13} \mathrm{C}-\mathrm{NMR}$ spectroscopy of the reaction products, (c) HPLC analysis of the reaction products, $(d)$ mass spectrometry of derivatized glyoxylate enzymically produced from isocitrate and $(e)$ radiography of derivatized glyoxylate enzymically produced from $\left[{ }^{14} \mathrm{C}\right]$ citrate. All these methods gave results consistent with the enzyme-catalysed conversion of isocitrate to glyoxylate and succinate.
\end{abstract}

\section{INTRODUCTION}

The metabolism of acetate or substrates which are converted to acetyl-CoA moieties without the intermediary generation of pyruvate proceeds through the tricarboxylic acid cycle (TCA cycle) and the glyoxylate cycle (Doelle, 1975; Lehninger, 1975; Schlegel, 1981). Dixon \& Kornberg (1959) were the first to demonstrate the occurrence of the two key glyoxylate cycle enzymes, isocitrate lyase and malate synthase. However, bacteria have been isolated which are able to grow on acetate or substrates such as ethanol or 3-hydroxybutyrate and which do not have measurable isocitrate lyase activity. Most if not all of these organisms belong to the group of facultative methylotrophs using the isocitrate lyase negative serine pathway during methylotrophic growth (Anthony, 1982). As methylotrophic or heterotrophic growth on $\mathrm{C}_{2}$ substrates apparently can occur without the presence of isocitrate lyase activity, these organisms were thought to possess an alternative metabolic route to generate glyoxylate. To obtain a better insight into the metabolism of acetate in an isocitrate lyase negative organism we chose Thiobacillus versutus, reported to lack isocitrate lyase (Gottschal \& Kuenen, 1980), for our experiments. The intermediary metabolism of acetate was analysed in vivo by ${ }^{13} \mathrm{C}-\mathrm{NMR}$ spectroscopy. $T$. versutus was adapted to anaerobic growth on acetate in the presence of nitrate for the preparation of NMR samples. This was done in order to facilitate the NMR experiments. Moreover, we assumed that by replacing oxygen by nitrate as electron acceptor the metabolism of the carbon and energy source would not be altered. Very surprisingly, however, $T$. versutus was found to possess isocitrate lyase activity during denitrifying growth on acetate, whereas during aerobic growth on the same substrate no activity was detected. In view of this finding we felt obliged to confirm the nature of the observed enzyme activity by identifying the reaction products.

Abbreviations: PMS, phenazine methosulphate; DCPIP, 2,6-dichlorophenolindophenol. 


\section{METHODS}

Organism, media and cultivation. Thiobacillus versutus, formerly called strain A2 (ATCC 25364; Harrison, 1983), was a gift from Dr J. G. Kuenen (Delft, The Netherlands). The organism was maintained on thiosulphate agar slants and subcultured every two months. The agar slants were stored at $4{ }^{\circ} \mathrm{C}$.

The basal medium for growth in chemostat culture contained, per 1 distilled water, $1.15 \mathrm{~g} \mathrm{KH}_{2} \mathrm{PO}_{4}$, $0.4 \mathrm{~g} \mathrm{MgSO}_{4} .7 \mathrm{H}_{2} \mathrm{O}, 0.4 \mathrm{~g} \mathrm{NH}_{4} \mathrm{Cl}$ and $2 \mathrm{ml}$ trace element solution (Gottschal \& Kuenen, 1980; Kuenen \& Tuovinen, 1981). For aerobic growth, sodium acetate or sodium succinate was added at a final concentration of $3.4 \mathrm{~g} \mathrm{l}^{-1}$. For denitrification, the medium used for aerobic growth was supplemented with $\mathrm{KNO}_{3}$ at a final concentration of $5.0 \mathrm{~g} \mathrm{l}^{-1}$ for acetate-limited growth, and $2.0 \mathrm{~g} \mathrm{l}^{-1}$ for nitrate-limited growth. The $\mathrm{pH}$ of the medium was adjusted to 5.0 before autoclaving. Cultures were grown at $30^{\circ} \mathrm{C}, \mathrm{pH} 8.0$, and at a dilution rate of $0.1 \mathrm{~h}^{-1}$. The $\mathrm{pH}$ was maintained at 8.0 by the automatic addition of $0.5 \mathrm{M}-\mathrm{H}_{2} \mathrm{SO}_{4}$. For aerobic growth, oxygen was supplied by sparging air through the culture at a rate of 11 air $(1 \mathrm{culture})^{-1} \mathrm{~min}^{-1}$. For anaerobic growth air was replaced by nitrogen (technical grade 3.0) at a rate of 0.251 ( 1 culture $)^{-1} \mathrm{~min}^{-1}$. Substrate limitations were determined from the proportional increase in optical density of the culture after an increase in substrate concentration in the medium reservoir.

For growth on thiosulphate or acetate (aerobic and denitrifying), the solid media described by Taylor \& Hoare (1969) were used, except for the trace element solution which was according to Gottschal \& Kuenen (1980). Sodium acetate was added at a final concentration of $2.5 \mathrm{~g}^{-1}$ and agar (Gibco) at a final concentration of $15 \mathrm{~g} \mathrm{I}^{-1}$. Inoculated thiosulphate or acetate plates were incubated aerobically. When acetate plus $\mathrm{KNO}_{3}$ plates were used incubation took place in a tightly closed jar in which oxygen was trapped after activation of a GasPak disposable hydrogen and carbon dioxide generator envelope (BBL) in the presence of a palladium catalyst. All incubations were done at $30^{\circ} \mathrm{C}$. The purity of the chemostat cultures was regularly checked by streaking samples from a dilution series onto agar plates. Samples from aerobic cultures were incubated on acetate in the presence of air; samples from anaerobic cultures were tested on acetate plus $\mathrm{KNO}_{3}$ plates under anaerobic conditions. The number of colonies obtained was compared to that found on aerobic thiosulphate plates inoculated with samples from the same dilution series.

Preparation of cell-free extracts. Cells were harvested from steady state chemostat cultures by centrifugation at $9000 \mathrm{~g}$ for $15 \mathrm{~min}$ in quantities of $\mathrm{OD}_{623} \times$ vol. (in $\mathrm{ml}$ ) $=100$. Pellets were washed with $30 \mathrm{~mm}$-potassium phosphate buffer, $\mathrm{pH} 7 \cdot 2$, and resuspended in $2 \mathrm{ml}$ of the same buffer. The cells were broken by sonication (four times for $30 \mathrm{~s}$ with $30 \mathrm{~s}$ intervals) using an ultrasonic disintegrator (MSE). After centrifugation at $20000 \mathrm{~g}$ for $20 \mathrm{~min}$ the supernatant was used for assays without further treatment except for dialysis if needed. In some experiments (see Results) the particulate fraction of the cell-free extract was removed by centrifugation at $120000 \mathrm{~g}$ for $2 \mathrm{~h}$. All manipulations were done at $4^{\circ} \mathrm{C}$. Protein concentrations were determined by the Lowry method with BSA as the standard.

Assays for determination of enzyme activity. Enzyme activities were measured in $1 \mathrm{ml}$ reaction mixtures $(1 \mathrm{~cm}$ cuvettes) in a Hitachi 101 spectrophotometer at $20^{\circ} \mathrm{C}$. The following assays were done in $50 \mathrm{mM}$-Tris/ $\mathrm{HCl}$ buffer, $\mathrm{pH} \mathrm{8.0:} \mathrm{(i)} \mathrm{isocitrate} \mathrm{lyase,} \mathrm{EC} \mathrm{4.1.3.1,} \mathrm{according} \mathrm{to} \mathrm{Dixon} \mathrm{\&} \mathrm{Kornberg} \mathrm{(1959),} \mathrm{in} 50 \mathrm{~mm}-\mathrm{MgCl}_{2}, 5 \mathrm{~mm}$ phenylhydrazine. $\mathrm{HCl}, 2 \mathrm{~mm}$-cysteine. $\mathrm{HCl}$ and $5 \mathrm{~mm}$-isocitrate; (ii) isocitrate lyase, according to Giachetti $e$ t al. (1984), in $2 \mathrm{mM}$-cysteine . $\mathrm{HCl}, 0.1 \mathrm{mM}-\mathrm{NADH}, 10 \mu \mathrm{l}$ lactate dehydrogenase (Boehringer) and $5 \mathrm{~mm}$-isocitrate; and (iii) succinate dehydrogenase, EC 1.3.99.1, according to Veeger et al. (1969), in 0.1 mM-PMS, 0.05 mM-DCPIP and $10 \mathrm{~mm}$-succinate. For the determination of isocitrate lyase activity according to Dixon \& Kornberg (1959), crude cell-free extract was used unless otherwise stated. For the assay according to Giachetti et al. (1984) only the soluble fraction of cell-free extract was added. The amount of protein used ranged from 40 to $300 \mu \mathrm{g}$. All reactions were started by adding substrate and followed for at least $2.5 \mathrm{~min}$. The observed rates were proportional to the amount of extract added.

Isocitrate lyase activity was also discontinuously measured by following the production of glyoxylate. In this case cell-free extract, 5 to $9 \mathrm{mg}$ protein, was incubated in $10 \mathrm{ml}$ assay mix containing $50 \mathrm{~mm}-\mathrm{Tris} / \mathrm{HCl}, \mathrm{pH} 8 \cdot 0$, $50 \mathrm{~mm}-\mathrm{MgCl}_{2}, 2 \mathrm{~mm}$-cysteine. $\mathrm{HCl}, 5 \mathrm{~mm}$-phenylhydrazine. $\mathrm{HCl}$ and $5 \mathrm{~mm}$-isocitrate. At regular intervals $0.2 \mathrm{ml}$ samples were removed. The reaction was stopped by adding $2.5 \mathrm{ml}$ concentrated $\mathrm{HCl}$. Any glyoxylate hydrazone formed was converted to 1,5-diphenylformazancarboxylic acid by adding $2.5 \mathrm{ml} 1 \%(\mathrm{w} / \mathrm{v}) \mathrm{K}_{3} \mathrm{Fe}(\mathrm{CN})_{6}$ as described by Kramer et al. (1959). After removal of precipitated protein, the $A_{532}$ was measured. The concentration of glyoxylate was calculated from a calibration curve.

${ }^{13} \mathrm{C}$-NMR spectroscopy. Dialysed cell-free extract (approximately $50 \mathrm{mg}$ protein) was incubated in a solution containing $30 \mathrm{~mm}$-potassium phosphate buffer, $\mathrm{pH} 7 \cdot 2,2 \mathrm{mM}$-cysteine. $\mathrm{HCl}, 1 \mathrm{mM}-\mathrm{MgCl}_{2}$ and $200 \mathrm{~mm}$-isocitrate. The final volume was $30 \mathrm{ml}$. This mixture was slowly stirred for $6 \mathrm{~h}$ at $30^{\circ} \mathrm{C}$. The reaction was terminated by boiling in a water-bath for $10 \mathrm{~min}$. After removal of denatured protein the samples were concentrated by lyophilization and subsequently resuspended in $3 \mathrm{ml}$ distilled water. ${ }^{13} \mathrm{C}-\mathrm{NMR}$ spectra were obtained at $75.46 \mathrm{MHz}$ on a Bruker CXP-300 NMR spectrometer equipped with a $10 \mathrm{~mm}$ probe operating in the Fourier transform mode. Proton broadband decoupling was applied throughout all experiments. The free induction decays 
(FIDs) were recorded by using a $45^{\circ}$ pulse (pulse time $8 \mu \mathrm{s}$ ) and 16000 data points. Approximately 55000 FIDs were accumulated. The temperature in the probe was kept at $270 \mathrm{~K}$. The observed resonances were identified by comparison with solutions of the pure compounds.

Product analyses. For all product analyses, cell-free extracts were incubated in an assay mix according to Dixon \& Kornberg (1959). The cell-free extract used was either crude extract, dialysed, or the soluble fraction alone. Incubation was done in a shaking water-bath at $30^{\circ} \mathrm{C}$ either under air in open tubes or in a degassed assay mixture in closed tubes under nitrogen. The specific details of the incubations are described in the legends of the respective figures. Samples were deproteinized by addition of $7 \%(\mathrm{v} / \mathrm{v})$ perchloric acid followed by neutralization with $\mathrm{KOH} / \mathrm{KHCO}_{3}$, or by adding $0.65 \mathrm{M}-\mathrm{H}_{2} \mathrm{SO}_{4}$ followed by neutralization with $\mathrm{KOH}$.

HPLC analyses. When samples were analysed for organic acids, phenylhydrazine was omitted from the assay mix. For cation exchange chromatography a Chrompack organic acids column $(6.5 \times 300 \mathrm{~mm})$ in the hydrogen form was used. The column temperature was set at $65^{\circ} \mathrm{C}$. Samples $(0.02 \mathrm{ml}$ for qualitative and $0.20 \mathrm{ml}$ for quantitative determinations) were eluted with $0.005 \mathrm{M}-\mathrm{H}_{2} \mathrm{SO}_{4}$ at a flow rate of $0.8 \mathrm{ml} \mathrm{min}-1$. Detection was at $206 \mathrm{~nm}$. For reverse phase chromatography a LKB Ultropac HPLC column $(4 \times 250 \mathrm{~mm})$, LiChrosorb RB-8 $(10 \mu \mathrm{m})$ was used at room temperature. Samples $(0.05 \mathrm{ml})$ were eluted with $5 \%(\mathrm{v} / \mathrm{v})$ acetonitrile in $20 \mathrm{mM}$ potassium phosphate buffer, $\mathrm{pH} 5.8$, at a flow rate of $1.5 \mathrm{ml} \mathrm{min}-1$ as described by Bellion et al. (1981). Detection of phenylhydrazones was at $313 \mathrm{~nm}$. All retention times $\left(R_{t}\right)$ were compared with retention times of pure solutions. Calibration curves were prepared by replacing cell-free extract by glyoxylate, succinate or fumarate.

Mass spectrometry (MS). Approximately $2 \mathrm{ml}$ deproteinized sample obtained after $2 \mathrm{~h}$ incubation of a cell-free extract of anaerobically grown cells in an assay mixture was chromatographed on a reverse phase column (see HPLC analyses). In the reference sample cell-free extract was replaced by $0.5 \mathrm{~mm}$-glyoxylate. Eluted fractions containing phenylhydrazone were collected, lyophilized and resuspended in $1 \mathrm{ml}$ distilled, acidified water. The phenylhydrazone was extracted in $5 \mathrm{ml}$ ethyl acetate. After rotary evaporation, the samples were used for MS. The mass spectrometer used was an AEI model MS-9. The probe temperature was set at $30^{\circ} \mathrm{C}$, the source temperature at $300^{\circ} \mathrm{C}$.

Radiography. To an assay mix in which isocitrate was replaced by $20 \mathrm{~mm}-\left[1,5-{ }^{14} \mathrm{C}\right]$ citrate (Amersham), diluted to a specific activity of $62.5 \mu \mathrm{Ci} \mathrm{mmol}^{-1}\left(2.31 \mathrm{MBq} \mathrm{mmol}^{-1}\right), 2.6 \mathrm{mg}$ protein of the soluble fraction of cell-free extract was added to give a final volume of $2 \mathrm{ml}$. No phenylhydrazine was added to the assay mix. The mixture was incubated in closed tubes for $45 \mathrm{~min}$. A deproteinized sample $(0.05 \mathrm{ml})$ was used for reverse phase HPLC (see HPLC analyses) after incubation with $10 \mathrm{mM}$-phenylhydrazine at $30^{\circ} \mathrm{C}$ for $30 \mathrm{~min}$. Eluted fractions were collected at intervals of $12 \mathrm{~s}$. After addition of $4 \mathrm{ml}$ Aqualuma Plus (Lumac/3M) radioactivity in the collected fractions was counted using an LKB 1211 Rackbeta liquid scintillation counter. The concentration of the glyoxylate phenylhydrazone in the sample was calculated from a calibration curve.

\section{RESULTS}

Isocitrate lyase activity was determined by the method of Dixon \& Kornberg (1959) in $T$. versutus after growth in five different chemostat cultures (Table 1). No isocitrate lyase activity was observed in aerobic cultures. In denitrifying cultures on acetate, however, the activity was found to be 52 and $111 \mathrm{nmol} \mathrm{min}^{-1}$ (mg protein) $)^{-1}$ in acetate-limited and nitrate-limited cultures, respectively. Cell-free extracts prepared from denitrifying succinate-limited cultures contained traces of, presumably, isocitrate lyase activity. Culture purity was confirmed from the agreement of the numbers of colonies on solid heterotrophic media with those obtained on solid media containing thiosulphate (Table 1). For the determination of isocitrate lyase activity according to Giachetti et al. (1984), in which the production of glyoxylate is followed by its reduction to glycollate in the presence of NADH and lactate dehydrogenase, NADH oxidase was removed by centrifugation at $120000 \mathrm{~g}$ for $2 \mathrm{~h}$. Again no isocitrate lyase activity was found in extracts from cells grown aerobically on acetate. The specific activity in the $120000 \mathrm{~g}$ supernatant of cell-free extracts of cells grown on acetate under denitrifying conditions was $63 \mathrm{nmol} \mathrm{min}{ }^{-1}$ (mg protein) $)^{-1}$ as determined by the method of Dixon \& Kornberg (1959) and $21 \mathrm{nmol} \mathrm{min}^{-1}$ (mg protein) $)^{-1}$ as determined by the method of Giachetti et al. (1984). Glyoxylate production by isocitrate lyase was also determined according to the method described by Kramer et al. (1959), in which glyoxylate is quantified after its conversion to 1,5diphenylformazancarboxylic acid. Using cell-free extract prepared from cells grown on acetate plus nitrate, 27 and $50 \mathrm{nmol}$ product $\min ^{-1}\left(\mathrm{mg}\right.$ protein) ${ }^{-1}$ were formed (determinations on two separate cultures). The activity was initially linear with time but decreased after approximately 60 min incubation. No product was formed using cell-free extract from aerobically grown cells. 
Table 1. Specific activity of isocitrate lyase in cell-free extracts and viable cell counts of

$T$. versutus from steady state chemostat cultures grown at a dilution rate of $0 \cdot 1 \mathrm{~h}^{-1}$

\begin{tabular}{|c|c|c|c|c|c|c|}
\hline \multirow[b]{3}{*}{$\begin{array}{l}\text { Respiratory } \\
\text { mode }\end{array}$} & \multirow[b]{3}{*}{$\begin{array}{l}\text { Limiting } \\
\text { nutrient }\end{array}$} & \multirow{3}{*}{$\begin{array}{c}\text { Isocitrate } \\
\text { lyase activity } \\
\text { [nmol min }{ }^{-1} \\
\left.(\text { mg protein })^{-1}\right]\end{array}$} & \multicolumn{4}{|c|}{$\begin{array}{c}10^{-8} \times \text { Viable cell count } \\
\quad\left(\text { bacteria } \mathrm{ml}^{-1}\right)\end{array}$} \\
\hline & & & & Gro & dium: & \\
\hline & & & Acetate & $\begin{array}{l}\text { Acetate } \\
+\mathrm{KNO}_{3}\end{array}$ & $\begin{array}{l}\text { Succinate } \\
+\mathrm{KNO}_{3}\end{array}$ & Thiosulphate \\
\hline Aerobic & Acetate & $0 \pm 1(n=15)$ & $94 \pm 16(n=5)$ & & & $88 \pm$ \\
\hline Denitrifying & Acetate & $52 \pm 18(n=16)$ & & $58 \pm 12(n$ & & $52 \pm 10(n=4)$ \\
\hline Denitrifying & Nitrate & $111(n=1)$ & & $36(n=1)$ & & $40(n=1)$ \\
\hline Aerobic & Succinate & $1(n=1)$ & & & & ND \\
\hline Denitrifying & Succinate & $1 \pm 2(n=8)$ & & & $69 \pm 10(n=3)$ & $68 \pm 14(n=3)$ \\
\hline
\end{tabular}

ND, Not determined.

For qualitative identification of the reaction products formed from isocitrate after incubation of cell-free extracts of cells grown with oxygen or nitrate as electron acceptor, ${ }^{13} \mathrm{C}-\mathrm{NMR}$ spectroscopy was used. As no ${ }^{13} \mathrm{C}$-enriched isocitrate was available, the assay was dependent upon the natural abundance of ${ }^{13} \mathrm{C}$ and thus large amounts of protein and substrate had to be used. The ${ }^{13} \mathrm{C}$-NMR spectra recorded are shown in Fig. 1. In spectrum (b) the presence of isocitrate, citrate, aconitate, glyoxylate, fumarate and malate was observed. In spectrum $(a)$ only isocitrate, citrate and aconitate were found. Apparently the extremely large amount of isocitrate in the assay mixture had strongly favoured the synthesis of aconitate and citrate by aconitase and citrate synthase, respectively. The absence of succinate in spectrum $(b)$ was presumably caused by conversion of succinate to fumarate and subsequently malate.

Cation exchange HPLC was used to determine the production of succinate and fumarate qualitatively and quantitatively after incubation of dialysed cell-free extracts for $2 \mathrm{~h}$. When cellfree extracts of $T$. versutus grown anaerobically on acetate plus nitrate were incubated under air, only fumarate was found (at a concentration of $0.076 \mathrm{mM}$ ). After incubation in a degassed, $\mathrm{N}_{2}$ flushed mixture, $1.04 \mathrm{~mm}$-succinate and $0.018 \mathrm{~mm}$-fumarate were formed. When succinate dehydrogenase activity was reduced to about $7 \%$ of its original value by removal of the particulate fraction, $1.17 \mathrm{~mm}$-succinate and $0.002 \mathrm{~mm}$-fumarate were formed. In cell-free extracts of aerobically grown cells succinate and fumarate were never observed. The production of succinate, fumarate and glyoxylate (after derivatization according to Kramer et al., 1959) was also determined as a function of time (Fig. 2). The amount of glyoxylate observed was not identical to the amount of succinate. This was due to the conversion of succinate to fumarate and malate. For a qualitative and quantitative determination of glyoxylate or any other hydrazone forming compound, samples obtained after incubation for $2 \mathrm{~h}$ were chromatographed using a reverse phase HPLC column. By comparison with a chromatogram of phenylhydrazones of glyoxylate, 2-oxoglutarate and pyruvate, the product in the sample derived from anaerobically grown cells was identified as glyoxylate. No phenylhydrazone was observed in the sample prepared from an assay mixture containing cell-free extract of aerobically grown cells. For further identification of the hydrazone, chromatographed fractions were collected, extracted in ethyl acetate and analysed by MS. The theoretical accurate mass of the glyoxylate phenylhydrazone is 164.0586 ; the accurate mass of the chemically formed glyoxylate phenylhydrazone was 164.0591 and that of the enzymically produced hydrazone was 164.0587 .

The origin of the glyoxylate was determined by radiography. As no $\left[{ }^{14} \mathrm{C}\right]$ isocitrate was commercially available $\left[1,5-{ }^{14} \mathrm{C}\right]$ citrate was used as substrate. Deproteinized samples were, after incubation with phenylhydrazine, chromatographed on a reverse phase HPLC column and the radioactivity in collected fractions was counted by liquid scintillation. The chromatogram and the distribution of the label are shown in Fig. 3. The majority of the radioactivity migrated without retardation. The concentration of the glyoxylate hydrazone was $0.26 \mathrm{~mm}$, calculated from a calibration curve. Therefore, as the specific activity of $\left[1,5-{ }^{14} \mathrm{C}\right]$ citrate was 

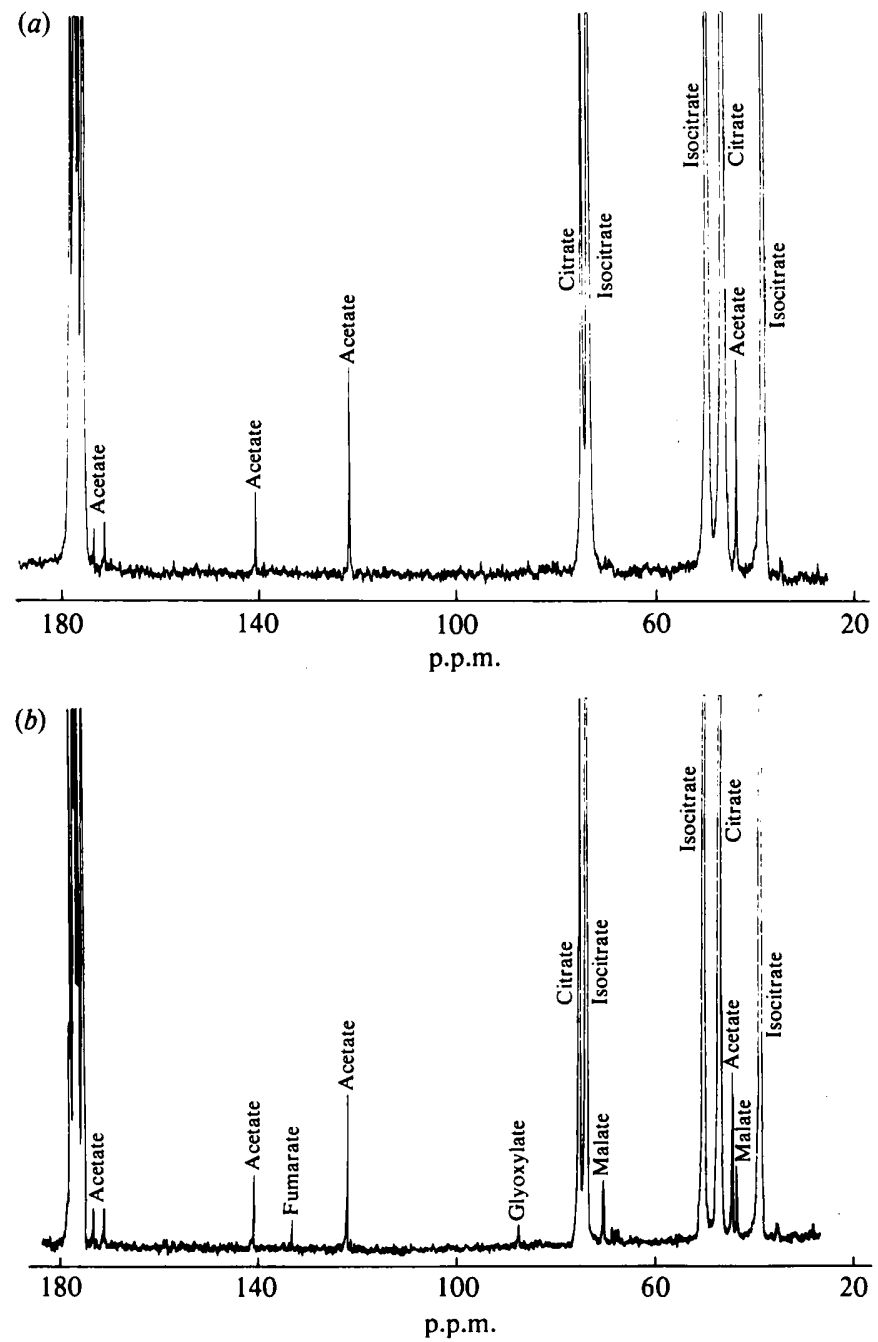

Fig. 1. Natural abundance ${ }^{13} \mathrm{C}-\mathrm{NMR}$ spectra of deproteinized samples obtained after incubation of dialysed cell-free extracts with isocitrate. (a) $T$. versutus from an aerobic acetate-limited chemostat culture; (b) $T$. versutus from a denitrifying acetate-limited chemostat culture.

$62.5 \mu \mathrm{Ci} \mathrm{mmol}^{-1}\left(2.31 \mathrm{MBq} \mathrm{mmol}^{-1}\right)$, the theoretical amount of glyoxylate hydrazone was 475 d.p.m. In the glyoxylate hydrazone fractions collected, a total of 492 d.p.m. was measured. An attempt was made to demonstrate the recovery of ${ }^{14} \mathrm{C}$ from $\left[1,5-{ }^{14} \mathrm{C}\right]$ citrate in succinate, or a product derived from succinate, by cation exchange chromatography. Because of co-migration of succinate and aconitate (directly formed from citrate) and the always very low concentration of fumarate, this attempt was unsuccessful.

\section{DISCUSSION}

Our results on (i) enzymic formation of a glyoxylate phenylhydrazone or 1,5diphenylformazancarboxylic acid, (ii) identification of glyoxylate and succinate as reaction products and (iii) recovery of ${ }^{14} \mathrm{C}$ from citrate in the glyoxylate fraction, leave no doubt as to the authenticity of the observed isocitrate lyase activity. Apparently $T$. versutus possesses the capacity to utilize the glyoxylate cycle when grown anaerobically on acetate in the presence of nitrate, i.e. during denitrifying growth on acetate. As in other micro-organisms (Dixon \& 


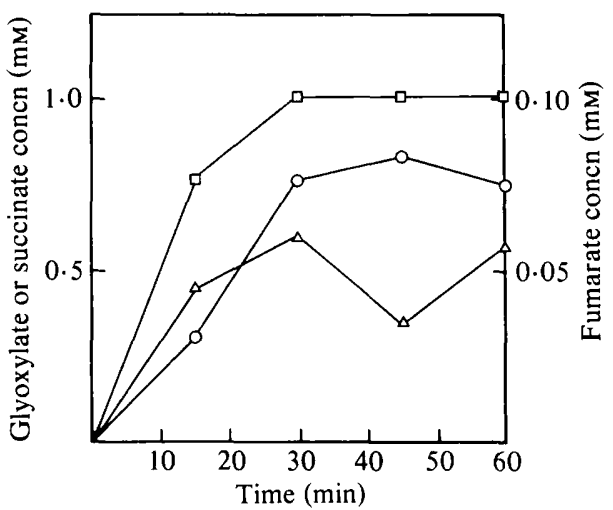

Fig. 2. Time course of succinate $(\triangle)$ and fumarate $(O)$ formation as determined by cation exchange HPLC, and of glyoxylate ( $\square$ ) formation as determined after its conversion to 1,5-diphenylformazancarboxylic acid. Incubation mixtures contained cell-free extract of $T$. versutus grown anaerobically on acetate and nitrate. Incubation conditions $(5 \mathrm{ml}$ vol.) were as described in Methods with two modifications: the concentration of Tris/ $\mathrm{HCl}, \mathrm{pH} 8.0$, was lowered to $5 \mathrm{mM}$ and $\mathrm{MgCl}_{2}$ was omitted. Incubation was done in a degassed, $\mathrm{N}_{2}$ flushed mixture; to this mixture $5.0 \mathrm{mg}$ protein was added. The specific activity of isocitrate lyase as determined from glyoxylate production was $50 \mathrm{nmol} \mathrm{min}^{-1}(\mathrm{mg}$ protein $)^{-1}$.

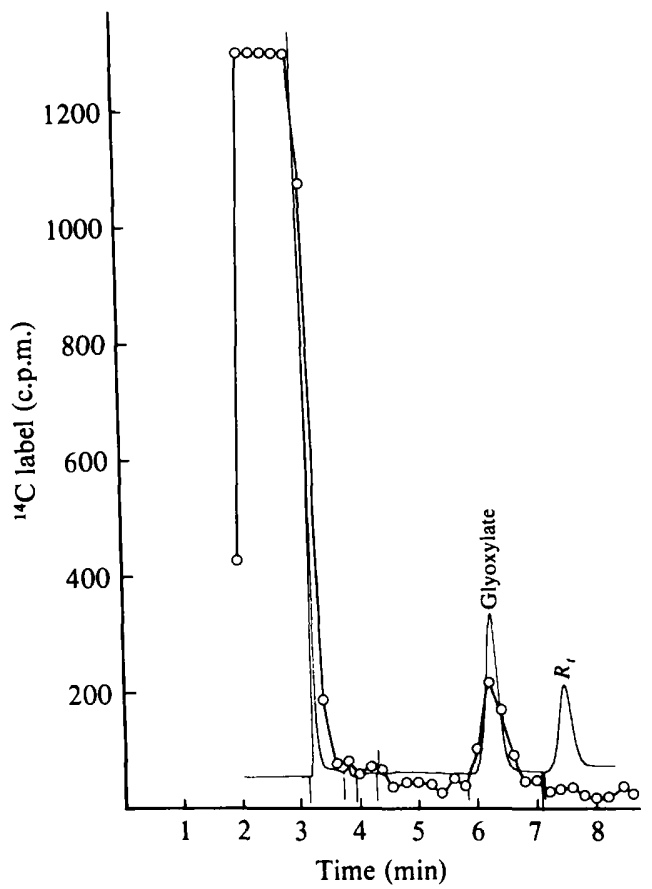

Fig. 3. Reverse phase HPLC chromatogram with ${ }^{14} \mathrm{C}$ label distribution $(O)$ of a deproteinized sample obtained after incubation of cell-free extract of $T$. versutus, grown anaerobically on acetate and nitrate, with $\left[1,5-{ }^{14} \mathrm{C}\right]$ citrate. Cell-free extract was prepared by centrifugation at $120000 \mathrm{~g}$ for $2 \mathrm{~h}$. Incubation conditions ( $2 \mathrm{ml}$ vol.) were as described in Methods; $2.6 \mathrm{mg}$ protein was added to the incubation mixture. The reaction was stopped after $45 \mathrm{~min}$. The $R_{t}$ of the glyoxylate phenylhydrazone was $6.22 \mathrm{~min}$. The peak at $7.47 \mathrm{~min}$ was not identified.

Kornberg, 1959; Lehninger, 1975; Schlegel, 1981), this isocitrate lyase activity was associated with growth on a $\mathrm{C}_{2}$ compound: hardly any activity was found after denitrifying growth on succinate. The observed specific activity of the enzyme in cells grown anaerobically on acetate 
and nitrate was not very high. However, the calculations by Quayle (1975) suggest that the specific activity is sufficient to maintain growth on acetate at a growth rate of $0 \cdot 1 \mathrm{~h}^{-1}$.

It is interesting to note that after incubation of cell-free extract obtained from anaerobically grown $T$. versutus with a large amount of isocitrate, not only glyoxylate and succinate can be detected, but also fumarate, malate, citrate and aconitate. The presence of these metabolites is most probably due to the activity of other TCA cycle enzymes, thus indicating that the TCA and glyoxylate cycles operate during denitrifying growth on acetate. This assumption is supported by the results of Peeters et al. (1970) who demonstrated the presence of all TCA cycle enzyme activities during denitrifying growth of $T$. versutus on succinate.

Having shown that $T$. versutus metabolizes acetate via the glyoxylate cycle under denitrifying conditions, we are left with the question of how this substrate is metabolized during aerobic growth. The lack of isocitrate lyase activity during aerobic growth on acetate has been observed previously with this organism (Gottschal \& Kuenen, 1980), and we similarly never found any activity with any of the methods reported here in spite of the ability of $T$. versutus to grow well on acetate under aerobic conditions. This replacement of one electron acceptor by another seemingly changes the route by which the growth substrate is metabolized. Explanation of this interesting phenomenon will require further work.

We are grateful to Dr G. J. J. Kortstee for his helpful discussions, to Mr M. W. Roelofsen for his technical assistance, and to Prof. Dr W. Harder and Dr J. P. van Dijken for their continued interest in this study. The investigations were supported by the Foundation for Fundamental Biological Research (BION), which is subsidized by the Netherlands Organization for the Advancement of Pure Research (ZWO).

\section{REFERENCES}

ANTHONY, C. (1982). The serine pathway of formaldehyde assimilation. In The Biochemistry of Methylotrophs, pp. 95-137. New York: Academic Press.

Bellion, E., Bolbot, J. A. \& Lash, T. D. (1981). Generation of glyoxylate in methylotrophic bacteria. Current Microbiology 6, 367-372.

Dixon, G. H. \& KornberG, H. L. (1959). Assay methods for key enzymes of the glyoxylate cycle. Biochemical Journal 72, 3p.

Doelle, H. W. (1975). Aerobic respiration - chemoorganotrophic bacteria. In Bacterial Metabolism, pp. 380-489. New York: Academic Press.

Giachetti, E., Pinzanti, G. \& Vanni, P. (1984). A new continuous optical assay for isocitrate lyase. Experientia 40, 227-228.

Gottschal, J. C. \& Kuenen, J. G. (1980). Mixotrophic growth of Thiobacillus A2 on acetate and thiosulfate as growth limiting substrates in the chemostat. Archives of Microbiology 126, 33-42.

HARrison, A. P., JR (1983). Genomic and physiological comparisons between heterotrophic Thiobacilli and Acidiphilium cryptum, Thiobacillus versutus sp. nov., and Thiobacillus acidophilus nom. rev. International Journal of Systematic Bacteriology 33, 211217.

Kramer, D. N., Klein, N. \& Baselice, R. A. (1959). Quantitative determination of glyoxylic acid. Analytical Chemistry 31, 250-252.
Kuenen, J. G. \& Tuovinen, O. H. (1981). The genera Thiobacillus and Thiomicrospira. In The Prokaryotes, vol. 1, pp. 1023-1036. Edited by M. P. Starr, H. Stolp, H. G. Trüper, A. Balows \& H. G. Schlegel. Berlin: Springer Verlag.

LEHINGER, A. L. (1975). The glyoxylate cycle. In Biochemistry, 2nd edn, pp. 466-467. New York: Worth.

Peeters, T. L., LiU, M. S. \& Aleem, M. I. H. (1970). The tricarboxylic acid cycle in Thiobacillus denitrifcans and Thiobacillus A2. Journal of General Microbiology 64, 29-35.

QUAYLE, J. R. (1975). Unsolved problems in the microbial metabolism of methane and methanol. In Microbial Growth on $C_{1}$-Compounds. Proceedings of the International Symposium on Microbial Growth on $C_{1}$-Compounds, pp. 59-65. Edited by $\mathrm{G}$. Terui. Tokyo: Society of Fermentation Technology.

ScHLEGEL, H. G. (1981). Hilfszyklen und Gluconeogenese. In Allgemeine Mikrobiologie, pp. 240-245. Stuttgart: Georg Thieme Verlag.

TAYLOR, B. F. \& HOARE, D. S. (1969). New facultative Thiobacillus and a reevaluation of the heterotrophic potential of Thiobacillus novellus. Journal of Bacteriology 100, 487-497.

Veeger, C., Der Vartanian, D. V. \& Zeylemaker, W. P. (1969). Succinate dehydrogenase. Methods in Enzymology 13, 82-83. 